Russia-Cyprus Relations 
This page intentionally left blank 


\section{Russia-Cyprus Relations}

\section{A Pragmatic Idealist Perspective}

Costas Melakopides

University of Cyprus 
All rights reserved. No reproduction, copy or transmission of this publication may be made without written permission.

No portion of this publication may be reproduced, copied or transmitted save with written permission or in accordance with the provisions of the Copyright, Designs and Patents Act 1988, or under the terms of any licence permitting limited copying issued by the Copyright Licensing Agency, Saffron House, 6-10 Kirby Street, London EC1N 8TS.

Any person who does any unauthorized act in relation to this publication may be liable to criminal prosecution and civil claims for damages.

The author has asserted his right to be identified as the author of this work in accordance with the Copyright, Designs and Patents Act 1988.

First published 2016 by

PALGRAVE MACMILLAN

Palgrave Macmillan in the UK is an imprint of Macmillan Publishers Limited, registered in England, company number 785998, of Houndmills, Basingstoke, Hampshire RG21 6XS.

Palgrave Macmillan in the US is a division of St Martin's Press LLC, 175 Fifth Avenue, New York, NY 10010.

Palgrave Macmillan is the global academic imprint of the above companies and has companies and representatives throughout the world.

Palgrave ${ }^{\circledR}$ and Macmillan ${ }^{\circledR}$ are registered trademarks in the United States, the United Kingdom, Europe and other countries.

ISBN 978-1-349-67460-2 ISBN 978-1-137-34715-2 (eBook)

DOI $10.1057 / 9781137347152$

This book is printed on paper suitable for recycling and made from fully managed and sustained forest sources. Logging, pulping and manufacturing processes are expected to conform to the environmental regulations of the country of origin.

A catalogue record for this book is available from the British Library.

Library of Congress Cataloging-in-Publication Data

Melakopides, Costas, author.

Russia-Cyprus relations: a pragmatic idealist perspective / Costas Melakopides. pages $\mathrm{cm}$

Includes bibliographical references.

1. Cyprus-Relations-Russia (Federation) 2. Russia (Federation)Relations-Cyprus. 3. Cyprus-History-Cyprus Crisis, 1974- I. Title. DS54.56.R87M45 2016

327.5693047-dc23 2015033203

Typeset by MPS Limited, Chennai, India. 


\section{Contents}

Preface and Acknowledgements vi

1 The "Pragmatic Idealist" Logic of the Book 1

2 The Cyprus Problem, International Law, and the Annan Plan

3 Revisiting Pragmatic Idealism: Assumptions, Main Concepts, and Some "Neighbouring" Theoretical Structures

4 Moscow's Policies towards Cyprus during the Cold War: Realpolitik versus Latent Pragmatic Idealism 44

5 Russia and Cyprus, 1991-2012: Pragmatic Idealism versus Realpolitik

6 Nicos Anastasiades' First Two Years in Power

7 The Russo-Turkish Labyrinth and the Cyprus-Egypt-Israel-Greece Rapprochement

8 Russo-Cypriot Prospects

Notes

Bibliography

Index 


\section{Preface and Acknowledgements}

When a young Russian-Greek woman from the State University of St Petersburg visited me at the University of Cyprus for an interview on Russia-Cyprus relations, in 2009, I could not surmise that the subject would become my solid preoccupation ever since. And yet, a combination of irresistible motives and goals conspired to keep me entangled in the labyrinthine investigations necessitated by the constant expansion of the book's horizons. For not only were the political, geostrategic and geo-economic developments under review being multiplied in often explosive ways while writing; there was also the realization that the book will have to revisit the convoluted and dramatic post-1950 political and geopolitical landscape of the Southern Balkans and the Eastern Mediterranean. In this manner, it could provide description, explanation, and evaluation of such post-World War II vicissitudes of Hellenism as the rejection of Athens' 1954 UN application for Cypriot self-determination; the EOKA anti-colonial struggle; the anomalous birth of the Republic of Cyprus (RoC); the Cypriot bi-communal conflict in the early 1960s; the Greek Colonels' dictatorship between 1967 and 1974; the double Turkish invasion of 1974; the ongoing Turkish military occupation of 37 per cent of Cypriot territory; the protracted, unsuccessful, efforts to settle the Cyprus problem in a civilized and functional manner; the unending Turkish threats, provocations, and blackmails; and the frequent deception by Washington and London which, while posing as "strategic partners" of the RoC, tolerate Ankara's illegality and immorality for transparent geopolitical reasons.

Given that Washington, Ankara, and London pursued policies that victimized Cyprus over and over again; and given that, in response, Moscow frequently came to defend and protect the interests and needs of the Greek Cypriots (GCs), this book will demonstrate the grounds for their gratitude and affection towards Moscow and the Russian people.

My analysis will be multi-causal and multidimensional, operating on all the levels on which I have found convincing evidence, that is, from the idiosyncratic to the bureaucratic and from the national to the regional and even the global. This is necessitated by the fact that most dramatic developments covered in this book had, overwhelmingly, a multiple external agency in addition to that of the internal actors. For while the Cypriots themselves both Greek and Turkish - as much as the Greeks of Greece were inescapably protagonists in living their history, it should not be assumed that they were also the exclusive authors of that history. London, Washington, and Ankara were at least co-authors, assisted during the last two decades by the United Nations Secretariat and some European Union circles. 
Needless to say, GCs and Turkish Cypriots (TCs) have certainly been guilty of serious errors and numerous sins during the post-World War II era. But the aforementioned three capitals did not distinguish themselves for defending the Cypriots' interests and needs. As regards the TCs, the book will make clear that they have also been victimized - and used - by Turkey's manipulation of their lives since the 1950s. Hence I will not harp on their own responsibilities during the double invasion of 1974 , since the focus will be on the principal actors of these crimes.

As for the GCs, this study will not argue for their innocence and purity of all motives; it will allocate blame as required. But this book, on the basis of rich evidence and a different logic, aims to show that the GCs have been unfairly accused of being primarily responsible for the ongoing Cyprus tragedy. After all, even if one were to pose the GCs as primarily "guilty" for the inter-communal troubles of late 1963-early 1964, it is impossible to argue that they "deserved" the 41 years of occupation and the massive violation of all their rights since, let alone during, Turkey's 1974 bloody invasion. Therefore, this study will cohere with other works that entail the thesis that the GCs were treated in both illegal and unethical ways since, besides their own weaknesses in terms of size of population and territory, their island has long titillated the geopolitical bulimia of countless powers over the centuries and continues to do so today.

This book's originality rests primarily on demonstrating, first, that Moscow has treated Cyprus in an overwhelmingly friendly, supportive, and protective manner; second, that - also overwhelmingly - this manner was premised on the values and norms of international law and international ethics; and third, that Moscow's Cyprus policies - as opposed to the policies of Washington, Ankara, and London - can explain the Greek Cypriots' affection for the Russian people and gratitude to Moscow.

It goes without saying that Moscow has also aimed to serve its own national needs and geopolitical interests throughout the period under review, especially during the nightmarish global antagonism of the Cold War. Given, however, that Moscow respected international legal norms and ethical values regarding Cyprus, whereas the other three actors have violated them variously and repeatedly, it follows that the Cyprus policies of the four capitals should not be studied identically. And yet, that is exactly how their Cyprus policies have been approached until the present book: namely, through the perspective, model or method of "political realism" or "power-politics".

This book, then, proposes to employ a different perspective that will bring into sharp relief the co-existence or cohabitation in Moscow's Cyprus policies of pragmatism (serving national or self-regarding goals) with idealism (representing respect for international legal and ethical principles and norms). This synthesis, that will determine this study's analytic tools, I call pragmatic idealism, to be discussed in Chapters 1 and 3. 
In the course of writing this book, I was forced to write and rewrite various political episodes and to close and reopen some more recent sections because of unexpected changes in the course of historical time causing serious diplomatic and geopolitical reversals. In addition, while my initial conception was to look closely at the special post-Cold War Russia-Cyprus relations, I concluded that the warm bilateral bonds could not have sprung ex nihilo after 1991: Moscow's attitudes were largely "pragmatic-idealist" even during the Cold War, since "idealist" elements existed for centuries in Russia's relations with Hellenism.

Cyprus' more recent adventures and vicissitudes made inevitable a survey of the Eastern Mediterranean geopolitical labyrinth created by numerous factors: Turkey's bellicosity and unpredictability; unending British and American meddling in Cyprus' domestic problems; Ankara's renewed aggressiveness in October 2014, which added the violation of Cyprus' sovereign rights in its Exclusive Economic Zone (EEZ) to Turkey's ongoing military occupation of 37 per cent of Cyprus; the discovery of promising natural gas deposits in Cyprus' and Israel's EEZs; Israeli and Egyptian interest in close association with Cyprus and Greece; Russia's renewed commitment to assist Cyprus in a variety of fields; and Greece's protracted socioeconomic crisis which led to the emergence of a dynamic leftist government in January 2015, itself pursuing strengthened relations between Hellenism and Moscow.

This book might occasionally exhibit a somewhat "polemical" tone, but this, I hope, will not hinder appreciation of its logic, which depends in part on the consciously adopted normative character of the analysis. For as explained in Chapter 3, this book's pragmatic-idealist perspective aims both to identify the "real" (that is, the "pragmatic-idealist") nature of Moscow's Cyprus policy, and to juxtapose it against that of the Anglo-Americans, and to do so by employing analytic tools that are obviously distinct from those of Realpolitik or "political realism". Needless to say, the criticism of the policies of the UK, the US, and Turkey does not reflect or entail any negative sentiments towards these countries' peoples. The criticism clearly amounts to opposition to their ruling elites' Cyprus-related unlawful and/or unethical decisions and actions.

As regards methodology (to be discussed in Chapters 1 and 3), I may mention here that my proposed theory respects both knowledge and understanding, since, besides Aristotelian logic, the reader will be occasionally invited to employ intuitions and inductions. Thus, my evidence will include the description and explanation of indisputable empirical facts; less familiar conclusions by numerous experts that seem solid and valid; archival material consulted either by myself or by other authors; numerous interviews with diplomats, politicians, and academics with integrity and rich experience; and the statements and judgements of Russian and Cypriot officials, ambassadors, respected authors, recognized columnists, and other experts. 
Now given that this text was submitted for final review in early May 2015, let me add here some broad observations on subsequent relevant developments. Thus, the Nicosia government continued cultivating its multifarious bonds with Moscow while also deepening Cyprus's multidimensional relations with Greece and the highly promising relations with Israel and Egypt. But Alexis Tsipras' government, embraced warmly by the Greek Cypriots since late January, was subjected to excruciating and near-humiliating treatment during the notorious Eurozone summit of 12-13 July 2015. For the Greeks of Cyprus, who sympathized profoundly with their Hellenic brethren, this experience demonstrated dramatically that, under Berlin's ascending quasi-hegemony, the emblematic EU values of solidarity, empathy, and democratic accountability were being undermined by a narrow-minded absolutism personified in the formalist ruthlessness of Wolfgang Schãuble. As Jürgen Habermas emphasized in a bold interview (The Guardian, 16 July 2015), while "a helpless European Council is effectively declaring itself politically bankrupt", Germany had "unashamedly revealed itself as Europe's chief disciplinarian and for the first time openly made a claim for German hegemony in Europe".

Inevitably, Greece's latest EU experience reshaped many Greek Cypriots' recollection of their own Eurozone-caused misery of March 2013. And yet, perhaps ironically, Greece's financial, economic, and socio-political vicissitudes generated, by mid-2015, a renewed recognition of the country's enormous geopolitical significance, as demonstrated by the energetic shuttle diplomacy, the countless high-level telephone calls, and the repeated offers of support extended towards Athens by both the Kremlin and the White House. Understandably, this was followed intensely by the Cypriot Greeks, eagerly envisaging possible implications for their republic's own political future, including the potential contemplation of Cyprus's own geopolitical value in tandem with Greece's. In addition, three European leaders attracted pan-Hellenic appreciation when they emerged as authentic friends and supporters of victimized Greece: French President Francois Hollande, Austrian Chancellor Werner Faymann and Italian Prime Minister Matteo Renzi. Finally, Nicos Anastasiades' enthusiastic jumping into new "bilateral negotiations" with newly elected TC leader Mustafa Akinci generated further strong criticism along the lines developed in Chapter 6. This because Cyprus's current weaknesses coupled with Greece's own crisis are confronting the provocative geopolitical ambitions of the Erdogan-Davutoglu duo, who naturally favour the "bizonal and bi-communal federation" that is inimical to the national interests of the Greek Cypriots and, arguably, to the geopolitical interests of Greece, Israel, Egypt, and the Russian Federation. Moreover, critics were being deeply disturbed by the transparent, antiaesthetic, and rather vulgar attempts to manipulate public opinion by the same circles that tried, but failed, to impose the Annan plan in 2004. Yet it was widely becoming the intuition that Greek Cypriots will again withstand 
the pressures to accept yet another toxic plan for the "resolution" of the Cyprus problem and that, if need be, Moscow would once again be willing and ready to act as a gigantic counter-weight.

Finally, I have the pleasure to thank warmly all the distinguished persons interviewed for this book and all the friends who supported me during a protracted creative adventure. Marina Salvaridi, the young student of the 2009 interview, gave me the stimulus to explore the exciting idiosyncrasies of this subject matter and was also co-author of my 2011 article in Russian. Next, I received sustained encouragement from my colleague, Dr Antonis Ellinas, who also read an earlier draft and provided valuable observations and comments. Professor Costas M. Constantinou, the Department Chairman, offered me his friendship, responded to my questions with sophistication and civility, and read Chapter 3, making excellent comments. It is also my pleasure to thank for their support the entire department, in particular Professor Stavros Tombazos, Dr Pavlos Koktsides, Dr Andis Loizides, Dr Stamatoula Panagakou, and Dr Lia-Paschalia Spyridou. Special thanks are due to Hannah Kaspar of Palgrave for her determined help, to Linda Auld and Elaine Bingham for their copyediting and to the reviewer who in June 2015 provided a decisive imprimatur. Lastly, for their own friendship, encouragement, and fruitful exchange of ideas, I wish to thank Andreas Dimou, Georgia Katsifaraki, and Sotos Vassiliou. 